\title{
Sexing of Bovine Embryos with Male-Specific Repetitive DNA by Polymerase Chain Reaction: Sexing of Bovine Embryos and Production of Calves with Predicted Sex
}

\author{
Yoshiaki ITAGAKI, Seiji SATO, Yuji SHITANAKA ${ }^{1)}$, \\ Toshiyuki KUDO, Yasumasa YAMAGUCHI ${ }^{1}$, and \\ Shizuyo SUTOU \\ Central Research Institute, Itoham Foods Inc., \\ 1-2 Kubogaoka, Moriya, Kitasoma, Ibaraki \\ 302-01, and ${ }^{1)}$ Kakogawa ET Center, Itoham \\ Foods Inc., 533 Shikata, Kakogawa, Hyogo \\ 657-03, Japan
}

\begin{abstract}
We have previously cloned and characterized both bovine male-specific and genderneutral DNA's. Primers for the polymerase chain reaction (PCR) were synthesized on the basis of these DNA's to give differential PCR products between males and females. Serial dilution of bovine somatic cells of both sexes revealed that 10 cells were sufficient to discriminate males from females under our conditions. The usefulness of our primers to sex bovine embryos was confirmed by using purified control DNA's, cytogenetic analysis of demi-embryos, coincidence of a pair of asymmetrical biopsy samples and embryo transfer. All the embryos used here were produced by in vitro fertilization and culture methods. A successful determination of sex was made for 83 out of 84 embryos examined $(98.8 \%)$. The sex ratio $(54.2 \%$ male) did not differ significantly from the expected $1: 1$ ratio. The viability of biopsied embryos (86.3\%) after $24 \mathrm{~h}$ culture in vitro was not significantly different from that of intact embryos $(92.3 \%)$. Also, the mean numbers of cells of the biopsied $(153.1, n=42)$ and intact $(170.7$, $n=39$ ) embryos were not significantly different. Out of seven recipients received the embryos with predicted sex, three went to term, producing one male and 2 female calves in accordance with the sex prediction before transfer. In conclusion, our method appears to be an efficient and reliable one to determine the sex of bovine preimplantation embryos.

Key words: Sexing, Bovine embryo, Bovine male-specific, Polymerase chain reaction.
\end{abstract}

(J. Reprod. Dev. 39: 65-72, 1993)

\footnotetext{
A mplification of Y chromosome-specific DNA's by means of the polymerase chain reaction (PCR) seems to be the most reliable and practical method to sex bovine preimplantation embryos [1-3] among several approaches so far examined. Some bovine male-specific DNA sequences have been patented [4-6] and viable calves of the sex predicted by PCR have been obtained $[7,8]$. We also independently cloned and characterized both

Accepted for Publication: January 11, 1993 Corrspondence: Y. Itagaki
}

bovine male-specific and gender-neutral DNA's, which provided us with suitable primers for PCR [9]. A combination of 2 pairs, male-specific and gender-neutral, gave discrete PCR amplification products which allowed us to discriminate male from female DNA's. Since our DNA sequences were repetitive in nature, detection efficiency was so high that sexing could be done with as little as $10 \mathrm{pg}$ of template DNA. For practical application in a commercial embryo transfer program, a sexing procedure must be accurate, efficient, 
rapid, and have no detrimental effect on embryos [10].

In this paper, we describe the validation of our primers for sex determination of bovine preimplantation embryos produced in vitro. Firstly, we determined the minimum number of cells needed to obtain the PCR amplification products by using various numbers of bovine somatic cells. Secondly, the validity of sex prediction of embryos by PCR was confirmed by the use of purified control DNAs, as well as by cytogenetic analysis of demiembryos and coincidence of asymmetrical biopsy samples. In addition, the subsequent developmental potential of sexed embryos was evaluated both in vitro and in vivo.

\section{Materials and Methods}

\section{Primers for PCR}

Two pairs of primers, one for a male signal and the other for a common signal to male and female, were used as described previously [9]. The bovine male-specific primers (5'-TGGACATTGCCACAACCATT-3' and 5'-GCTGAATGCACTGAGAGAGA-3') gave a PCR product of $226 \mathrm{bp}$ and the bovine gender-neutral primers (5'-GCCCAAGTTGCTAAGCACTC-3' and 5'-GCAGAACTAGACTTCGGAGC-3'), one of $102 \mathrm{bp}$. These oligonucleotides were synthesized with an automatic DNA synthesizer (Applied Biosystems, model 391).

Preparation of bovine somatic cells of known sex

The liver from a Holstein of known sex was obtained at a local slaughterhouse. The liver was dissected into minute blocks, which were then placed on the surface of culture dishes. After attachment, they were cultured in Dulbecco's modified minimal essential medium, supplemented with $10 \%$ calf serum, in a $\mathrm{CO}_{2}$ incubator. Outgrowths of epithelial-like cells were obtained. The number of cells was counted with a hemocytometer; a cell suspension was serially diluted with phosphate buffered saline for PCR.

\section{Production of embryos in vitro}

Bovine blastocysts were produced by in vitro fertilization and culture methods. Follicular oocytes with compacted cumulus cells collected from Japanese Black or Holstein ovaries at a slaughterhouse were cultured in $400-\mu$ l droplets of
TCM-199 medium containing $25 \mathrm{mM}$ HEPES (Sigma Chemical Co.), with 5\% heat-treated calf serum, $0.5 \mathrm{mM}$ sodium pyruvate, and antibiotics (100 units $/ \mathrm{ml}$ penicillin and $100 \mu \mathrm{g} / \mathrm{ml}$ streptomycin) under mineral oil for $23-24 \mathrm{~h}$ at $39 \mathrm{C}$ in $5 \%$ $\mathrm{CO}_{2}$ in air [11]. These in vitro matured oocytes were inseminated by frozen-thawed bull-sperm capacitated with heparin [12]. After co-incubation with sperm in BO medium [13] supplemented with heparin and caffeine for $5 \mathrm{~h}$, the presumptive zygotes with cumulus cells were transferred to the same medium which had been used for in vitro maturation, and cultured for 7-8 or 9-10 days until development to expanded blastocysts or hatched blastocysts, respectively. These conditions allowed the cumulus cells originally surrounding the oocytes/embryos to form a monolayer on the bottom of the dish [14]. Only expanded blastocysts showing a distinct inner cell mass and a distinct trophoectoderm within the zona pellucida were used for micromanipulation.

\section{Micromanipulation of embryos}

The embryos chosen for micromanipulation were placed individually in $50-\mu \mathrm{l}$ droplets of PBI medium [15] without bovine serum albumin (BSA), but supplemented with $0.2 \mathrm{M}$ sucrose, under mineral oil in a culture dish (Corning, 60 $\mathrm{mm}$ non-treated polystyrene dish). The embryos were incubated for at least $5 \mathrm{~min}$ at room temperature to allow them to undergo osmotic equilibration (partial dehydration) and become attached to the bottom of the dish. The attachment was not rigid, so that the orientation of the embryos could be adjusted at will using a bore pipette. The dish was placed on an inverted microscope (TMD 10, Nikon) equipped with a right-handed micromanipulator (MO-188, Narishige) with a microblade (Biocut blade, No. 715, Feather Safety Razor Co.).

The biopsy procedure employed in this study was similar to that reported by Herr and Reed [1], except that the zona pellucida was not sliced off, but was partly cut open. That is, by a single descending movement of the microblade, the zona pellucida was cut open asymmetrically and a small part of the cell mass (approximately 10\%) of the trophoectoderm was split off. To obtain demiembryos, embryos were bisected with a single downward motion of the microblade through the zona pellucida, bisecting the inner cell mass and trophoectoderm. 
The micromanipulated embryos left in the original zona pellucida could be easily detached from the bottom of the dish by adding a small amount of culture medium containing calf serum directly into the medium for micromanipulation. The whole procedure of micromanipulation could be completed within $10 \mathrm{~min}$.

\section{PCR amplification and gel electrophoresis}

The conditions for PCR amplification were similar to those described previously for genomic DNA [9].

To each of the tubes containing the samples, 100 $\mu \mathrm{l}$ of reaction mixture consisting of $10 \mathrm{mM}$ Tris-HCI ( $\mathrm{pH} 8.9$ ), $1.5 \mathrm{mM} \mathrm{MgCl} 2,80 \mathrm{mM} \mathrm{KCI}$, $0.1 \%$ sodium cholate, $0.1 \%$ Triton X-100, $50 \mu \mathrm{M}$ dNTPs, $0.2 \mu \mathrm{M}$ DNA primers and 2 units of Tth DNA polymerase was added and overlaid with 50 $\mu \mathrm{l}$ of mineral oil. The PCR amplification was performed with a DNA thermal cycler (Perkin Elmer Cetus) by 50 cycles of denaturation ( $94 \mathrm{C}, 1$ $\mathrm{min})$, annealing (60 C, $1 \mathrm{~min}$ ), and primer extension $(72 \mathrm{C}, 1 \mathrm{~min})$. Ten microliter aliquots of amplified products were electrophoresed in $3 \%$ NuSieve 3:1 agarose (FMC BioProducts) gels in a Tris-borate-EDTA buffer. After electrophoresis, the amplified fragments were visualized directly by ethidium bromide staining and ultraviolet illumination.

\section{Determination of number of cells and cytogenetic analysis}

In order to count the numbers of cells removed from the trophoectoderm and those present in viable embryos after micromanipulation, samples were fixed essentially as described by Ushijima $e t$ al. [16]. Each sample or embryo was subjected to hypotonic treatment in $0.9 \%$ sodium citrate for 3-5 min, transferred to a fixative (methanol:acetic acid: distilled water $=3: 2: 1 \mathrm{v} / \mathrm{v}$ ) for $10-30 \mathrm{sec}$, spread and fixed on a grease-free slide, followed by the addition of 1 or 2 drops of acetic acid. The slides were stained in 5\% Giemsa solution for 6 $\mathrm{min}$. For cytogenetic analysis, demi-embryos were cultured in the presence of colcemid $(0.04 \mu \mathrm{g} / \mathrm{ml})$ for $4 \mathrm{~h}$ before hypotonic treatment.

\section{Evaluation of micromanipulated embryo viability in vitro}

The micromanipulated embryos were cultured individually in $50-\mu \mathrm{l}$ droplets of the culture medium with a monolayer of cumulus cells, which had been proliferated on the bottom of dishes, of the same age of the embryos. After $24 \mathrm{~h}$ culture in vitro, embryos classified as excellent or good were considered to have survived.

Evaluation of the sexed embryo viability in vivo

After sexed embryos had re-formed a blastocoel within the zona pellucida, they were transferred to Holstein or cross-bred recipients. Transfers were performed nonsurgically into the uterine horn ipsilateral to the cotrpus luteum of recipients on day 7 or 8 of the estrous cycle. Pregnancies were determined by rectal palpation and echography at 45-50 days after transfer.

\section{Statistical analysis}

The chi-square $\left(\chi^{2}\right)$ test was used to assess the significance of differences between 2 discrete sets data and Student's $t$ test for similar evaluation of means.

\section{Results}

\section{Minimal number of cells for PCR}

Before sampling of embryonal cells, the minimal number of cells needed for PCR was determined by using different numbers of cultured bovine somatic cells of both sexes. When 1, 3, 10, 30, and 100 cells were tested, male signals were obtained from 10 or more cells. No male signal was detected in any of the female samples (Fig. 1). In the previous report [9], we have shown that the minimal amount of DNA required for PCR analysis was $10 \mathrm{pg}$, equivalent to DNA from 3 cells. The present results obtained from cultured cells indicate slightly lower sensitivity as compared with the case of purified DNA. This discrepancy may arise from differences between the expected and actual numbers of cells, since test samples were prepared by serial dilution. In any case, 10 cells were enough for PCR to give a male signal.

\section{PCR with whole hatched blastocysts}

Our PCR test was next applied for sexing of bovine embryos. Firstly, a total of 30 whole hatched blastocysts were subjected to PCR. All embryo samples gave unequivocal results, corresponding 18 males and 12 females, on comparison with positive control signals obtained from $1 \mathrm{ng}$ of 


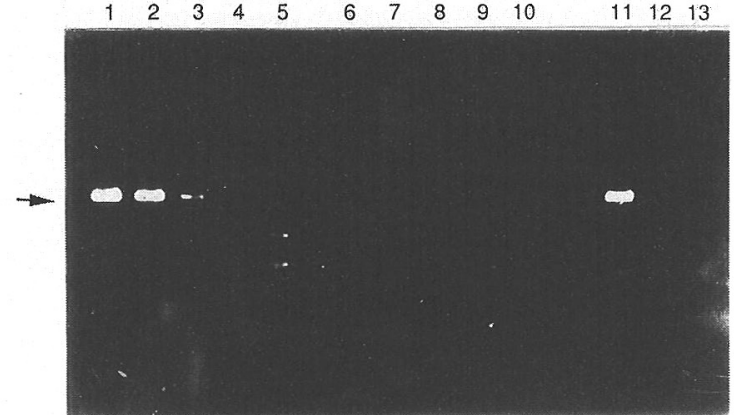

Fig. 1. Agarose gel electrophoresis of PCR products from various numbers of somatic cells. The number of cells was 100 for lanes 1 and 6,30 for lanes 2 and 7, 10 for lanes 3 and 8,3 for lanes 4 and 9 , and 1 for lanes 5 and 10. Lane 1 through 5 show male cells and lane 6 through 10 , female cells. Lane 11 shows purified male DNA and lane 12, female DNA (1 ng each). Lane 13 shows phosphate buffered saline, used as the negative control. An arrow shows male-specific PCR product.

purified DNA of both sexes (Fig. 2). Thus, our test condition were shown to be applicable to embryos without interference by embryonic cellular components.

\section{Sex determination by $P C R$ and cytogenetic analysis}

To confirm the results of PCR, cytogenetic analysis was used as an alternative method of embryo sexing. Following bisection of embryos, one demi-embryo was immediately subjected to PCR, while the other was cultured to evaluate the viability and then analyzed cytogenetically. When
42 pairs of demi-embryos were thus examined by the two methods, all demi-embryos could be successfully sexed by PCR (20 males and 22 females), whereas only 19 demi-embryos could be cytogenetically analyzed (10 males and 9 females). These data indicated that success in embryo sexing by cytogenetic analysis (45.2\%) is greatly inferior to that by PCR (100\%). So far as the 19 embryos analyzed by both methods are concerned, PCR and cytogenetic analysis gave identical results.

The number of cells removed from the trophoectoderm

In biopsy, the removal of only small samples is important for retention of full developmental ability of the embryos following their transfer. Data from this study indicated that at least 10 cells are required for PCR. Samples taken 23 embryos were fixed immediately after biopsy to count the number of cells. The number of cells was $11.8 \pm 5.9$ (mean \pm S.D.), and so it appears that an adequate sample could be taken with minimal damage to the biopsied embryos as described below.

Viability and number of cells of embryos cultured for $24 \mathrm{~h}$ after micromanipulation

The micromanipulated embryos were cultured individually for $24 \mathrm{~h}$ to evaluate their viability and the number of cells. As a control, intact expanded blastocysts were cultured under the same conditions.

The viability of embryos is presented in Table 1. There was no significant difference in viability

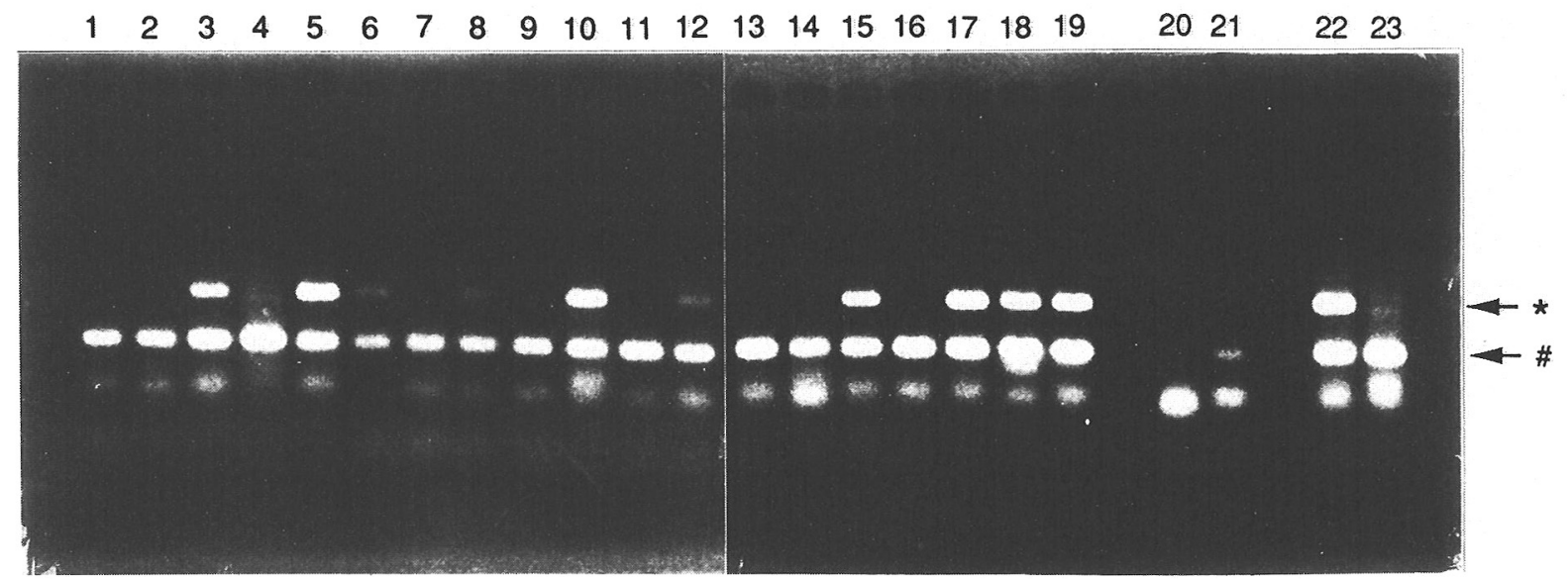

Fig. 2. Agarose gel electrophoresis of PCR products from whole hatched blastocysts. Lanes $3,5,6,8,10,12,15,17$, 18 , and 19, males; lanes $1,2,4,7,9,11,13,14$, and 16, females; lanes 20 and 21, medium (less than $5 \mu$ ); lane 22, purified bovine male DNA ( $1 \mathrm{ng})$; and lane 23, purified bovine female DNA (1 ng). Male-specific ( $\star$ ) and gender-neutral (\#) PCR products are shown by arrows. 
Table 1. In vitro viability of bovine embryos cultured for $24 \mathrm{~h}$ after micromanipulation

\begin{tabular}{lcll}
\hline $\begin{array}{l}\text { State of } \\
\text { embryos }\end{array}$ & $\begin{array}{l}\text { No. of } \\
\text { embryos }\end{array}$ & $\begin{array}{l}\text { No. of } \\
\text { viable } \\
\text { embryos }\end{array}$ & $(\%)$ \\
\hline Intact & 78 & 72 & $(92.3)^{\mathrm{a}}$ \\
Biopsied & 73 & 63 & $(86.3)^{\mathrm{a}}$ \\
Bisected & 71 & 55 & $(77.5)^{\mathrm{b}}$ \\
\hline
\end{tabular}

Statistically significant difference at $\mathrm{P}<0.05$ between $\mathrm{a}$ and $\mathrm{b}$.

between the intact $(92.3 \%)$ and the biopsied (86.3\%) embryos. Most embryos in both groups expanded and developed to hatching or hatched blastocysts (48/72 viable embryos for the intact and $58 / 63$ for the biopsied). The viability of demiembryos $(77.5 \%)$ was significantly lower than that of the intact embryos. It was also lower than that of the biopsied embryos, although no significant difference was seen. Most demi-embryos were small in size and remained in the zona pellucida.

The numbers of cells in the embryos after in vitro culture for $24 \mathrm{~h}$ are shown in Table 2. The mean numbers of cells of the intact $(170.7 \pm 44.6$, $\mathrm{n}=39)$ and biopsied $(153.1 \pm 53.3, \mathrm{n}=42)$ embryos were not significantly different. Significant differences were seen in the mean numbers of cells between demi-embryos $(67.5 \pm 23.2, n=42)$ and half-embryos equivalent to the intact embryos $(85.5 \pm 22.2, \mathrm{n}=39)$.

These data indicate that the biopsy procedure employed in this study is not severely detrimental to the embryos.

Validation of sex determination with asymmetrical biopsy samples

Before carrying out embryo transfer experiments, we confirmed that sex determination of the asymmetrical biopsy samples, i.e., the small parts of cell mass removed from the trophoectoderm and the remainders of the embryos, gave identical results.

Thirty-six embryos were biopsied as described above. The biospy samples, which were expected to contain approximately 12 cells on average, were subjected to PCR immediately after biopsy. The remainders of the embryos were cultured for $24 \mathrm{~h}$ to evaluate the viability. Thirty-three embryos $(91.1 \%)$ were viable after in vitro culture. A total of
Table 2. Numbers of cells in bovine embryos cultured for $24 \mathrm{~h}$ after micromanipulation

\begin{tabular}{lcc}
\hline $\begin{array}{l}\text { State of } \\
\text { embryos }\end{array}$ & $\begin{array}{l}\text { No. of embryos } \\
\text { fixed }\end{array}$ & $\begin{array}{c}\text { No. of cells } \\
\text { (mean } \pm \text { SD) }\end{array}$ \\
\hline Intact & 39 & $170.7 \pm 44.6^{\mathrm{a}}$ \\
Biopsied & 42 & $153.1 \pm 53.3^{\mathrm{a}}$ \\
Bisected & 42 & $67.5 \pm 23.2^{\mathrm{b}}$ \\
Half intact- & 39 & $85.5 \pm 22.2^{\mathrm{c}}$ \\
$\quad$ embryo equivalent & & \\
\hline
\end{tabular}

Statistically significant difference at $\mathbf{P}<0.01$ between a and $\mathrm{b}, \mathrm{a}$ and $\mathrm{c}$, and $\mathrm{b}$ and $\mathrm{c}$.

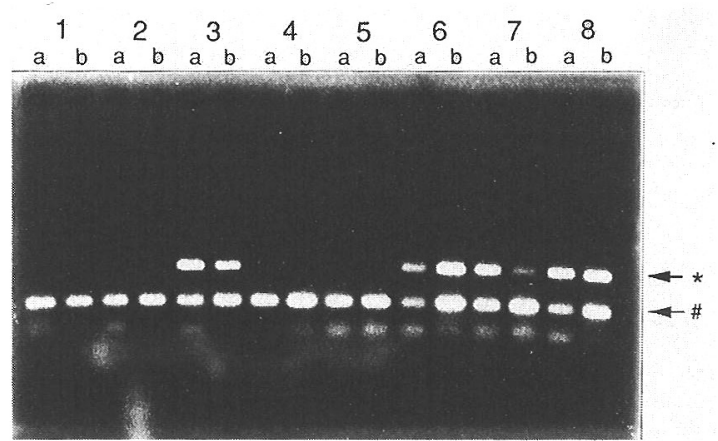

Fig. 3. Agarose gel electrophoresis of PCR products from biopsied samples and viable embryos. Lanes 1a-8a were biopsied samples and lanes $1 \mathrm{~b}-8 \mathrm{~b}$, viable embryos. Each combination of $a$ and $b$ gave the same result, so that lanes $3,6,7$, and 8 were estimated to be from males and lanes $1,2,4$, and 5 , from females. Male specific $\left(^{*}\right)$ and gender-neutral (\#) PCR products are shown by arrows.

32 viable embryos which were expected to contain approximately 153 cells on average, were then subjected to PCR. In all but one case $(96.9 \%)$, each pair clearly showed the same results, i.e., both males or females; there were 16 males and 15 females (Fig. 3).

\section{Evaluation of sexed embryo viability in vivo}

A total of seven recipients received 2 male and 5 female embryos, as determined by sex prediction by PCR. Four recipients $(57.1 \%)$ were confirmed to be pregnant at 45 to 50 days. One abortion occurred at 72 days. The remaining 3 recipients went to term, producing one male and 2 females in accordance with the sex prediction before transfer. 
Table 3. Validation of PCR-sexing of bovine embryos produced in vitro

\begin{tabular}{|c|c|c|c|c|c|}
\hline \multirow{2}{*}{$\begin{array}{l}\text { Condition } \\
\text { of embryo } \\
\text { samples }\end{array}$} & \multirow{2}{*}{$\begin{array}{l}\text { No. of } \\
\text { embryos } \\
\text { applied }\end{array}$} & \multicolumn{3}{|c|}{ No. successfully sexed } & \multirow[b]{2}{*}{ Validation } \\
\hline & & Male & Female & Total $(\%)$ & \\
\hline Whole & 30 & 18 & 12 & $30(100)$ & Purified DNA of both sexes \\
\hline Half & 19 & 10 & 9 & $19(100)$ & Cytogenetic analysis \\
\hline Partial & 32 & 16 & 15 & $31^{\mathrm{a}}(96.9)$ & Identity with biopsy samples \\
\hline Partial & 3 & 1 & 2 & $3(100)$ & Embryo transfer \\
\hline Total & 84 & 45 & 38 & $83(98.8)$ & \\
\hline
\end{tabular}

a, Discrepancy between assays, in one case.

The sex ratio of embryos produced in vitro as determined by PCR

The results of a validation study of sex prediction of embryos by PCR are summarized in Table 3. In 83 of 84 samples $(98.8 \%)$ subjected to PCR in this study, a successful determination of sex was made; the remaining one gave contradictory results in the asymmetrical biopsy samples. The sex ratio in this study $(54.2 \%)$ did not differ significantly from the expected 1:1 ratio, although more male embryos than females.

\section{Discussion}

The results of the present study clearly indicate that our method is an efficient and reliable one to determine the sex of bovine preimplantation embryos.

While PCR amplification techniques allow DNA sequences in a single cell to be analyzed [17], it is difficult to identify and handle an extremely small number of cells from the embryo, and the possibility of contamination during embryo manipulation and amplification is increased. On the other hand, the removal of large numbers of cells remarkably limits full developmental ability of the embryos to be transferred. In the present study, special attention was paid to these problems.

Firstly, we used bovine male-specific DNA sequences which are highly repetitive [9]. A single copy of gene related to $\mathrm{Y}$ chromosome-specific DNA sequences, e.g., the homolog of the testis determining factor gene cloned in mouse (Sry) [18] and human (SRY) [19], is an apparently attractive candidate as a probe for sexing. However, although such a single copy gene is highly specific to the $\mathrm{Y}$ chromosome, a repetitive gene has a higher copy number and so allows the use of a smaller biopsy sample. The detection limit with our primers corresponds to about 10 cells, which is acceptable for the present purpose.

The use of 2 pairs of primers, i.e., male-specific and gender-neutral, is important to ensure accuracy. The use of the latter makes it possible to detect an experimental error such as loss of the embryo sample. Only one ambiguous result was obtained in the present study, and the reason for this single discrepancy (female from the biopsy sample, male from the remaining viable embryo) is not clear at present; there may have been a technical error in handling the embryo or biopsy.

During micromanipulation of the embryos, they were exposed to protein-free medium for a short time. Omission of BSA from the medium has 2 advantages, as follows: 1) preventing contamination with amplifiable bovine DNA, and 2) allowing the embryos to become fixed to the bottom of the dish without the aid of a holding pipette.

The micromanipulation techniques for biopsy employed in this study provided high viability and good quality of embryos. Data on the in vitro viability of biopsied embryos are limited. According to Peura et al. [8], 79 embryos produced in vitro were bisected for sex determination by PCR and the total survival rate was $53 \%$ after overnight culture. A recent embryo bisection study by LucasHahn and Niemann [20] showed $92.3 \%$ viability of demi-embryos after $24 \mathrm{~h}$ in vitro culture. This discrepancy of viability may depend upon differences in the many variables, including production of embryos, bisection method, culture conditions, and technical expertise of the operator. In this study, viability of bisected embryos was lower than that of the intact embryos, though there was no 
significant difference in viability between the intact and biopsied embryos. Our conditions of coculture with cumulus cells of the embryos (averaging 170.7 cells) were similar to those used in a bovine oviducal epithelial cell co-culture system ( 174.7 cells in hatching blastocysts) by Xu et al. [21] with regard to number of cells. Under the same conditions, the average number of the cells per biopsied embryo was 153.1. This value is rather lower than that of the intact embryos, but the difference is not significant. In contrast, demiembryos had 67.5 cells, less than half the number in biopsied embryos. Thus, the biopsy procedure employed in this study may not have grossly affected the developmental potential of the embryos. In addition, the mean number of cells (11.8) removed from the embryos was sufficient for PCR.

In respect of the sex ratio of preimplantation embryos, our findings of more male embryos (54.2\%) than females, although the difference from the expected 1:1 ratio was not statistically significant, is in agreement with previous reports $[22,23]$.

Several groups have obiained viable calves from embryos after sex determination by the PCR procedure [7, 8]. High accuracy has been reported by Herr et al. [7], where 11/12 (91.6\%) calves were of the predicted sex. Peura et al. [8] obtained a calving rate with in vitro produced embryos of $44.5 \%$ (8 calves/ 18 demi-embryos) and all the sexes were as predicted. In our experiment, the transfer of a single embryo into each recipient resulted in 3 calves from 7 sexed embryos (43\%) and the sex of all 3 calves was as predicted.

The main part of this study was focused on the establishment of a reliable technique for sexing of bovine embryos so that we did not evaluate the developmental ability of sexed embryos after cryopreservation. Bondioli et al. [22] reported a pregnancy rate with frozen-thawed embryos biopsied for sexing of $40 \%$, which is an acceptable range for commercial application. However, some investigators have suggested that more experiments are needed to overcome the sensitivity of micromanipulated embryos to freezing and thawing [20]. Establishment of cryopreservation procedures for biopsied (or sexed) embryos would be of considerable commercial value in combination with an embryo transfer program.

\section{References}

1. Herr CM, Reed KC. Micromanipulation of bovine embryos for sex determination. Theriogenology 1991; 35: 45-54.

2. Peura T, Hyttinen J-M, Turunen M, Janne J. A reliable sex determination assay for bovine preimplantation embryos using the polymerase chain reaction. Theriogenology 1991; 35: 547-555.

3. Setiabudi R, Gustavsson I. Establishment of embryo sexing techniques in Sweden. Reprod Dom Anim 1991; 26: 78-81.

4. Ellis SB, Harpold MM. Nucleic acid probes prenatal sexing. PCT WO 86/07095 1986.

5. Bishop CE, Cotinot C, Fellous M, Kirszenbaum M, Vaiman M. Sondes d'ADN specifique genome male des ruminants leur preparation et utilisation. EPO 235046A1 1987.

6. Reed KC, Matthews MA, Jones MA. Sex determination in ruminants using $\mathrm{Y}$-chromosome specific polynucleotides. PCT WO 88/01300 1988.

7. Herr CM, Holt NA, Matthaei KI, Reed KC. Sex of progeny from bovine embryos sexed with a rapid Y-chromosome-detection assay. Theriogenology 1990; 33: 247 (abstract).

8. Peura T, Hyttinen J-M, Turunen M, Aalto J,
Rainio V, Jänne J. Birth of calves developed from embryos of predetermined sex. Acta Vet Scand 1991; 32: 283-286.

9. Kudo T, Sato S, Sutou S. Sexing of bovine embryos using male-specific repetitive DNA by polymerase chain reaction. I. Cloning and characterization of bovine male-specific repetitive DNA. J Reprod Dev 1993; 39: 55-63.

10. First NL. New animal breeding techniques and their application. J Reprod Fert 1990; 41 (suppl): 3-14.

11. Hanada A. In vitro fertilization in cattle. With particular reference to sperm capacitation by ionophore A23187. Jpn J Anim Reprod 1985; 31: 56-61 (In Japanese).

12. Parrish JJ, Susko-Parrish JL, Leibfried-Rutledge ML, Critser ES, Eyestone WH, First NL. Bovine in vitro fertilization with frozen-thawed semen. Theriogenology 1986; 25: 591-600.

13. Brackett BG, Oliphant G. Capacitation of rabbit spermatozoa in vitro. Biol Reprod 1975; 12: 260-274.

14. Fukuda Y, Ichikawa M, Naito K, Toyoda Y. Birth of normal calves resulting from bovine oocytes 
matured, fertilized, and cultured with cumulus cells in vitro up to the blastocyst stage. Biol Reprod 1990; 42: 114-119.

15. Whittingham DG. Survival of mouse embryos after freezing and thawing. Nature 1971; 233: 125-126.

16. Ushijima H, Eto T, Ogawa S. Sexing of bovine halved embryos by karyotyping and transfer of the sexed demi-embryos. Jpn J Anim Reprod 1989; 35: 63P-68P (In Japanese).

17. Li H, Cui X, Arnheim N. Direct electrophoretic detection of the allelic state of single DNA molecules in human sperm by using the polymerase chain reaction. Proc Natl Acad Sci USA 1990; 87: 4580-4584.

18. Gubbay J, Colligan J, Koopman P, Capel B, Economou A, Munsterberg A, Vivian N, Goodfellow $\mathbf{P}$, Lovell-Badge $\mathbf{R}$. A gene mapping to the sex determining region of the mouse $\mathrm{Y}$ chromosome is a member of a novel family of embryonically expressed gene. Nature 1990; 346: 245-250.

19. Sinclair AH, Berta P, Palmer MS, Hawkins JR, Griffiths BL, Smith MJ, Foster JW, Frischauf A,
Lovell-Badge R, Goodfellow PN. A gene from the human sex-determining region encodes a protein with homology to a conserved DNA-binding motif. Nature 1990; 346: 240-244.

20. Lucas-Hahn A, Niemann $\mathbf{H}$. In vitro survival of fresh and frozen/thawed bovine demi-embryos. Theriogenology 1991; 36: 619-627.

21. Xu KP, Yadav BR, Rorie RW, Plante L, Betteridge KJ, King WA. Development and viability of bovine embryos derived from oocytes matured and fertilized in vitro and co-cultured with bovine oviducal epithelial cells. J Reprod Fert 1992; 94: 33-43.

22. Bondioli KR, Ellis SB, Pryor JH, Williams MW, Harpold MM. The use of male-specific chromosomal DNA fragments to determine the sex of bovine preimplantation embryos. Theriogenology 1989; 31: 95-104.

23. King WA, Yadav BR, Xu KP, Picard L, Sirard M-A, Supplizi AV, Betteridge KJ. The sex ratios of bovine embryos produced in vivo and in vitro. Theriogenology 1991; 36: 779-788. 